\title{
Allelopathic Effect of the Coffee Residue in Emergency and Urochloa brizantha Growth
}

\author{
Bruno Manoel Rezende de Melo1, Tácio Peres da Silva ${ }^{2 *}$, Douglas Goulart Castro², \\ Flávia Barbosa Silva Botelho², Emily Renata Moreira1', Suelen Simão Gomes ${ }^{1}$, \\ Heloisa Oliveira dos Santos ${ }^{1}$ \\ ${ }^{1}$ Instituto Federal de Educação, Ciência e Tecnologia do Sul de Minas Gerais—Campus Inconfidentes, Inconfidentes/MG, Brasil \\ ${ }^{2}$ Universidade Federal de Lavras, UFLA, Lavras/MG, Brasil \\ Email: ${ }^{\star}$ tacioagro@gmail.com
}

How to cite this paper: de Melo, B.M.R., da Silva, T.P., Castro, D.G., Botelho, F.B.S., Moreira, E.R., Gomes, S.S. and dos Santos, H.O. (2018) Allelopathic Effect of the Coffee Residue in Emergency and Urochloa brizantha Growth. American Journal of Plant Sciences, 9, 637-644.

https://doi.org/10.4236/ajps.2018.94050

Received: December 14, 2017

Accepted: March 9, 2018

Published: March 12, 2018

Copyright (c) 2018 by authors and Scientific Research Publishing Inc. This work is licensed under the Creative Commons Attribution International License (CC BY 4.0).

http://creativecommons.org/licenses/by/4.0/

\section{(c) (i) Open Access}

\begin{abstract}
Weed management is important for the increase of agricultural crops, since they have a negative influence on yield and harvest quality. To optimize the management it is possible to use the coffee infusion residues, which has caffeine contents, a substance that has an allelopathic effect to some plants. Thus, the goal was to evaluate the allelopathic effect of coffee residues in the emergence and growth of Urochloa brizantha under product doses, gathering and application seasons in pre- and post-emergence. The experiment was carried out at UFLA, in a greenhouse with potting, with Urochloa brizantha seeds, cultivar Piatã, in DBC with three replicates in the factorial $(3 \times 4 \times 2)$ : time of gathering $(\mathrm{A}, \mathrm{B}, \mathrm{C})$; concentration of ground $(0,20,50$ and $100(\% \mathrm{~W} / \mathrm{V}))$ and pre- and post-emergence application. The height, fresh and dry weight, Emergence Speed Index-ESI and phytotoxicity were evaluated. It was verified the significance for pre-emergence treatments, reducing plant height, increasing phytotoxicity and reducing fresh weight. For the ESI, it was identified that only for gathering season obtained a significant result. In the phytotoxicity evaluations, it obtained interaction for the season of application with residue gathering season. For product doses and applications in pre- and post-emergence interaction was observed for phytotoxicity. It is concluded that the residue has allelopathic effect reducing growth and increasing phytotoxicity up to a maximum dose of 55.83 and 86.76 for pre- and post-emergence applications of Urochloa brizantha.
\end{abstract}

\section{Keywords}

Caffeine, Organic Waste, Phytotoxicity 


\section{Introduction}

Agribusiness presents strategic importance for Brazil both for food production, as well as for energy and fiber production, impacting significantly on gross domestic product.

In this context, one of the factors that still has relevance for agricultural losses is the occurrence of weeds that compete with agricultural crops for factors such as water, light, space, and nutrients [1]. Besides this influence, these plants can present allelopathic effect [2], also acting as host of pests and interfering in the harvest.

For the proper management of invasive plants, it is necessary to associate mechanisms that benefit its control. Among them, we can point out the use of molecules that may present allelopathic effect. Control alternatives must constantly be incorporated into management systems considering the resistance of certain weeds to some herbicide molecules.

When these resistances are verified in some crop management strategies, they must be adopted to guarantee satisfactory control, taking into account the sustainability assumptions.

In this context, the study of new management practices meets the recurrent demand of our agriculture. In this line of research, some authors have already verified the interference of caffeine in the establishment of weeds that according to [3], this substance causes a reduction of invasive plants around the coffee plant, possibly associated with canopy caffeine washing of coffee.

The application of this allelochemical can induce the appearance of abnormal seedlings, in which necrosis is the most evident symptom of the allelopathic effect, contributing to inhibit the growth of the host plant [4].

[5] evaluated the allelopathic effect of the application of exogenous caffeine on the germination and growth of embryos of $C$. arabica L. and $C$. canephora Pierre, who concluded that these parameters were affected by the addition of exogenous caffeine, since as the amount of this alkaloid increased, the embryo rooting percentage was lower for the two species studied, significantly affecting the fresh mass of the embryos.

Caffeine, chemically known as 1,3,7-trimethylxanthine, presents a $\mathrm{C} / \mathrm{N}$ ratio of $22 / 1$, the nitrogen content of $2.3 \%$ [6] being present in several parts of coffee plants, including in the grains and in the residues.

For the sustainable use of this molecule, it is possible to use the coffee infusion residues, a substance that presents from $0.02 \%$ to $0.08 \%$ of caffeine [7].

Therefore, the objective was to evaluate the allelopathic effect of coffee residues in the emergence and growth of Urochloa brizantha under product doses, gathering season and pre- and post-emergence application.

\section{Material and Methods}

The experiment was conducted in a greenhouse at the Federal University of Lavras, in the Department of Agriculture, located at the geographical coordinates: 
Latitude $21^{\circ} 14$ 'S, Longitude $45^{\circ} 00^{\prime} \mathrm{W}$, and the average altitude of 920 meters, with humidity of $70 \%$, temperature ranging from $26^{\circ} \mathrm{C}$ to $34^{\circ} \mathrm{C}$ and photoperiod of 12 hours.

Seeding was carried out in May 2017, in 8 liters pots, in which soil was filled with a dystroferric red Latosol, and 100 seeds of Urochloa brizantha cultivar BRS Piatã were sown in each pot, with a cultural value of $75 \%$ at depth of $2 \mathrm{~cm}$. The seeds were donated by SOESP. This cultivar presents erect growth, height of 0.85 to 1.10 meters, medium tolerance to drought, perennial vegetative cycle and requires soil average fertility [8]. The sowing of the Urochloa occurred 21 days after the filling of the pots with soil, they were kept in a greenhouse under irrigation so that the seed bank present in the soil could germinate occurring later its withdrawal. Irrigations were performed by micro nebulizers up to field capacity.

The experiment was carried out in randomized blocks (RBD), with three replicates, in the factorial $(3 \times 4 \times 2)$, the first factor: residue gathering times: 1$)$ collected on the same day of use; 2 ) collected every day for 10 days and refrigerated storage after each gathering at $4^{\circ} \mathrm{C} ; 3$ ) gathering performed on the first day and stored in refrigerator for 10 days at $4^{\circ} \mathrm{C}$; second factor: coffee ground doses in percentage $(\mathrm{W} / \mathrm{V})$ at doses of $0 \%, 20 \%, 50 \%$ and $100 \%$ and third factor: time of application: pre- and post-emergence, constituting 24 treatments and 72 experimental plots.

Pre-emergence applications occurred the day after sowing and post-emergence applications occurred after the emergence of $60 \%$ of seedlings.

The mixture of the solute with the solvent was carried out in a blender with stirring for one minute and then $100 \mathrm{ml}$ of the solution was applied in each plot.

The evaluated parameters were: plant height 39 days after seeding, evaluating five plants per plot, performing with millimeter ruler, fresh and dry mass of the aerial part, performed in a forced circulation air at $60^{\circ} \mathrm{C}$ to weight constant, with weighing done on a precision scale; analysis of phytotoxicity assessed through grading scale from 0 to 100 (total destruction [9]), carried out by three people counting the average of the evaluators' scores and the emergency speed index (ESI) according to the methodology of [10]. The counting was carried out until the seedlings reached stability in the germination.

$$
E S I=\frac{N_{1}+N_{2}+\cdots+N_{n}}{D_{1}+D_{2}+\cdots+D_{n}}
$$

At where:

$E S I=$ emergency speed index;

$N=$ number of seedlings verified on the day of the count;

$D=$ numbers of days after sowing at which the counting was performed.

For the characteristic evaluated within each treatment, the analysis of variance and the comparison of the average by the Tukey test at $5 \%$ of probability for the qualitative analysis were performed. For the quantitative analysis, the polynomial models were used for the effect of input doses. The criterion for the model selection will be the significance by the $\mathrm{F}$ test at $5 \%$ probability of error that pre- 
sented a higher coefficient of determination $\left(\mathrm{r}^{2}\right)$. Statistical analysis was performed in the statistical software Sisvar [11]. The normality of the data was verified according to the Lilliefors test [12], through the application genes [13]. Data that did not present normal distribution were transformed by the equation $(\mathrm{x}+$ 1) $\times 0.5$.

\section{Results and Discussions}

For the height variable, there was no interaction of the factors, identifying significance only for the application time factor, and the pre-emergence application showed lower plant height, Table 1.

As the reduction of height was observed in the pre-emergence treatment, it assumes that the residue presents better assimilation of the residue at the seed stage, provoking a cytotoxic effect due to the nuclear alterations inducing the binucleate of the meristematic cells [14], or acting in the post emergence, since seedlings at this stage are more sensitive to environmental stresses.

This reduction in growth is probably related to the compound caffeine, a thermostable substance that is highly soluble in water, inhibiting seed germination or seedling growth [15].

[16] applying coffee residues, observed a decrease in lettuce, carrot and spinach growth, revealing that the inhibition of $\mathrm{N}$ and $\mathrm{P}$ mineralization had an inhibitory effect on plant growth, which may also be associated with the presence of caffeine. The same author states that the results in the literature are still contradictory but the main reason for such inhibition should be related to the presence of caffeine which may have reduced the availability of nitrogen to the plants.

The ESI was not affected by the interaction of the factors, presenting significance only for gathering seasons, which reduced the emergence for gathering season A and B. A higher ESI was observed and statistically different for gathering season $C(p$-value $=0.014)$, Table 2. May et al. [17] verified that in treatments

Table 1. Plants height with application of coffee residues in pre-emergence and post-emergence.

\begin{tabular}{cc}
\hline Treatments & Height \\
\hline Pre-emergence & $7.3 \mathrm{a}$ \\
Post-emergence & $8.12 \mathrm{~b}$ \\
$\mathrm{CV}(\%)$ & 11.3 \\
\hline
\end{tabular}

Averages followed by the same letter do not differ statistically from each other at $5 \%$ probability.

Table 2. Emergency speed index (ESI) for gathering season of coffee residues.

\begin{tabular}{cc}
\hline Gathering season & ESI \\
\hline A & $34.16 \mathrm{a}$ \\
B & $34.41 \mathrm{a}$ \\
C & $38.26 \mathrm{~b}$ \\
CV (\%) & 14.62 \\
\hline
\end{tabular}

Averages followed by the same letter do not differ statistically from each other at 5\% probability. 
with coffee husks at different doses they had lower germination as an increase in the concentration of the extracts, which was not verified for the doses of the product.

The dry weight was not influenced by any of the treatments, however, for the fresh weight, there was a significant effect, isolated, for the application seasons, and it was found a lower weight for the pre-emergence when compared to post-emergence, Table 3, showing a smaller volume of plants exploring the area, which may influence less competition with the agricultural crop. [18] analyzed that the aqueous extract of coffee husk caused an increasing linear effect in the dry matter production of the caruru, not corroborating with the results found in relation to the different materials but with caffeine in common.

The evaluated phytotoxicity allowed to verify the interaction between the gathering season of the residue and the application season, verifying that for the gathering season A, applied in pre-emergence the phytotoxicity was significant presenting 2.42 more phytotoxicity than the treatment in post-emergence, Table 4. For the interaction, pre-emergence application, the highest phytotoxicity was identified for the gathering season A, Table 5, possibly associated to a higher solubility of caffeine at room temperature, considering that the other residue gathering season remained in the refrigerator.

In the interaction for the 100 dose of residue at the application season, significance was identified for the data, and 2.41 times greater phytotoxicity was observed for preemergence application, Table 5 . This may be associated with the damage caused in the radicles of the plants in the initial stage of development which directly influences the absorption of water and nutrients causing injuries in the aerial part. For the lower doses probably no result was obtained considering that the caffeine is strongly retained in the soil clays in similar proportions [19]. Therefore, higher doses present greater availability of caffeine.

For the interaction of residue doses for pre- and post-emergence applications, it is observed that for the pre-emergence application the dose of 86.76 grams obtained greater phytotoxicity, Figure 1(a), for application in post-emergence the dose that caused highest phytotoxicity was 55.83 grams, Figure 1(b).

This curve inflection is probably observed with increasing doses in response to inhibition of the caffeine effect by some compound present in the residue. According to [20], the decrease in inhibition with increasing concentration suggests that extracts of low concentration of Arabica coffee could contain concentrations of other substances that would stimulate germination. The same author

Table 3. Fresh weight for pre and post-emergency applications.

\begin{tabular}{cc}
\hline Treatments & Fresh weight \\
\hline Pre-emergence & $3.97 \mathrm{a}$ \\
Post-emergence & $4.64 \mathrm{~b}$ \\
$\mathrm{CV}(\%)$ & 23.29 \\
\hline
\end{tabular}

Averages followed by the same letter do not differ statistically from each other at $5 \%$ probability. 
Table 4. Interaction between gathering season with application season for analysis of phytotoxicity.

\begin{tabular}{ccc}
\hline Residue gathering season & Residue application season & Phytotoxicity Index \\
\hline A & Pre-emergence & $24.17 \mathrm{a}$ \\
& Post-emergence & $10.00 \mathrm{~b}$ \\
\hline Residue application season & Residue gathering season & Phytotoxicity Index \\
\hline \multirow{2}{*}{ Pre emergence } & $\mathrm{a}$ & $24.16 \mathrm{~b}$ \\
& $\mathrm{~b}$ & $15.00 \mathrm{a}$ \\
$\mathrm{CV}(\%)$ & $\mathrm{c}$ & $14.58 \mathrm{a}$ \\
\hline
\end{tabular}

Averages followed by the same letter do not differ statistically from each other at 5\% probability.

Table 5. Dose interaction with time of application for phytotoxicity evaluation.

\begin{tabular}{ccc}
\hline Residue dose & Residue application season & Phytotoxicity index \\
\hline \multirow{2}{*}{100} & Pre-emergence & $29.44 \mathrm{a}$ \\
& Post-emergence & $12.22 \mathrm{~b}$ \\
CV (\%) & & 24.64 \\
\hline
\end{tabular}

Averages followed by the same letter do not differ statistically from each other at $5 \%$ probability.

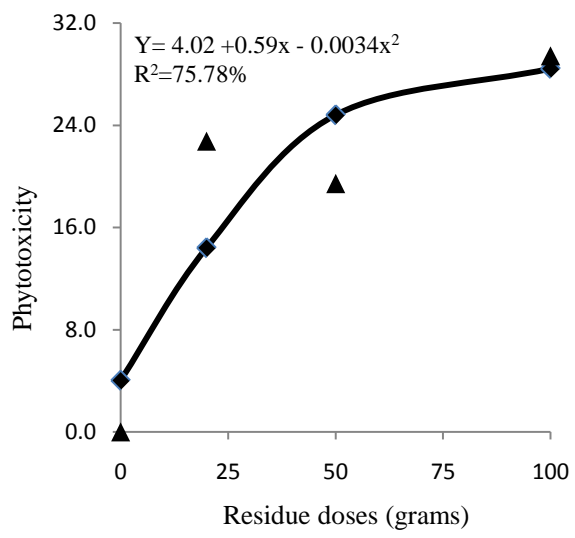

(a)

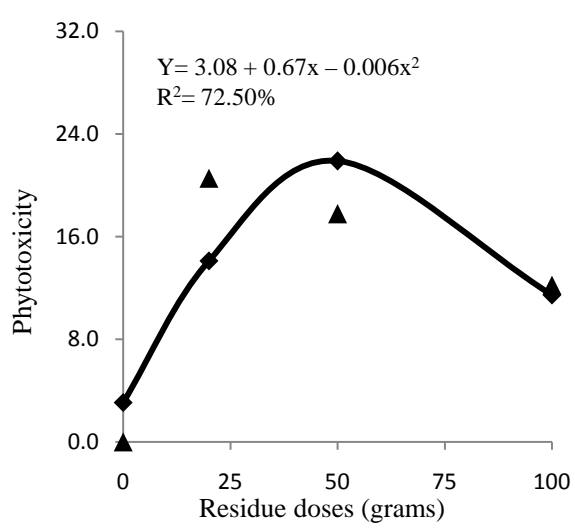

(b)

Figure 1. Interaction of the residue doses for pre-emergence (a) and post-emergence (b) applications for phytotoxicity analysis. 
points out that arabica coffee straw extract at concentrations of $25 \%$ and $50 \%$ $(\mathrm{v} / \mathrm{v})$ indicated a greater inhibitory effect on germination, whereas at the concentration of $100 \%(\mathrm{v} / \mathrm{v})$ it favored germination.

[21] concludes that increasing coffee residue doses increases the delay in the growth of tomato seedlings, noting that the inhibitory effect may be associated with secondary metabolites causing allelopathy, such as caffeine.

\section{Conclusions}

Allelopathic effect of the residue was verified for pre-emergence applications to reduce height, fresh weight, and phytotoxicity.

Product doses showed a quadratic effect on phytotoxicity of Urochloa brizantha.

The ESI was reduced due to the gathering season of gathering residue.

\section{Acknowledgements}

To the "Federal Institute of Education, Science and Technology of South of Minas Gerais-Campus Inconfidentes" for the concession to leave the qualification, the Federal University of Lavras for the equipment used and the company Sementes do Oeste Paulista SOESP ${ }^{\oplus}$, for the donation of the seeds.

\section{References}

[1] Vasconcelos, M.C.C., Silva, A.F.A. and Lima, R.S. (2012) Interferência de plantas daninhas sobre plantas cultivadas. Agropecuária Científica no Semiárido, 8, 1-6.

[2] Duarte, N.F., Silva, J.B. and Souza, I.F. (2002) Competição de plantas daninhas com a cultura do milho no município de Ijaci, MG. Ciência e Agrotecnologia, 5, 983-992.

[3] Friedman, J. and Waller, G.R. (1983) Seeds as Allelopathic Agents. Journal of Chemical Ecology, 9, 1107-1117. https://doi.org/10.1007/BF00982215

[4] Ferreira, A.G. and Áquila, M.E.A. (2000) Alelopatia: Uma área emergente da ecofisiologia. Revista Brasileira de Fisiologia Vegetal, 12, 175-204.

[5] Rosa, S.V.F., Santos, C.G., Paiva, R., Melo, P.L.Q., Veiga, A.D. and Veiga, A.D. (2006) Inibição do desenvolvimento in vitro de embriões de Coffea por cafeína exógena. Revista Brasileira de Sementes, 28, 177-184. https://doi.org/10.1590/S0101-31222006000300025

[6] Mussatto, I.S., Machado, E.M.S., Martins, S. and Teixeira, J.A. (2011) Production, Composition and Application of Coffee and Its Industrial Residues. Food and Bioprocess Technology, 4, 661-672. https://doi.org/10.1007/s11947-011-0565-z

[7] Fan, L. and Soccol, C. (2005) Shiitake Bag Cultivayion. Parte I Shiitake. Coffee Residues. Mushroom Grower's Handbook. Mushworld All 2, 92-94.

[8] Nantes, N.N., Euclides, V.P.B., Montagner, D.B., et al. (2013) Desempenho animal e características de pastos de capim-piatã submetidos a diferentes intensidades de pastejo. Pesquisa Agropecuária Brasileira, 48, 114-121. https://doi.org/10.1590/S0100-204X2013000100015

[9] Rolim, J.C. (1989) Proposta de utilização da escala. European Weed Research Coouncil (EWRC) modificada em ensaios de campos com herbicidas. Araras: IAA/PLANALSUCAR. Coordenadoria Regional sul, 3 p. (Mimeorg) 
[10] Maguire, J.D. (1962) Speed Germination-Aid in Selection and Evaluation for Seedling Emergence and Vigor. Crop Science, 2, 176-177. https://doi.org/10.2135/cropsci1962.0011183X000200020033x

[11] Ferreira, D.F. (2011) Sisvar: A Computer Statistical Analysis System. Ciência e Agrotecnologia (UFLA), 35, 1039-1042. https://doi.org/10.1590/S1413-70542011000600001

[12] Campos, H. (1983) Estatística experimental não paramétrica. Esalq, Piracicaba.

[13] Cruz, C.D. (2013) GENES-A Software Package for Analysis in Experimental Statistics and Quantitative Genetics. Acta Scientiarum, 35, 271-276.

[14] Ferreira, A.D. (2011) Influência da borra de café no crescimento e nas propriedades químicas e biológicas de plantas de alface (Lactuca sativa L.). Dissertação de Mestrado em Qualidade e Segurança Alimentar, Escola Superior Agrária, Bragança.

[15] Chou, C.H. and Waller, G.R. (1980) Possible Allelopathic Constituents of Coffea arabica L. Journal of Chemical Ecology, 6, 643-639. https://doi.org/10.1007/BF00987675

[16] Cruz, S.A.F. (2015) Avaliação do potencial da borra de café fresca na mineralização do nitrogênio e do fósforo e em culturas hortícolas. Dissertação, Universidade de Lisboa, (Engenharia do Ambiente) Instituto Superior de Agronomia, Lisboa, 67 p.

[17] May, D., Rocha, L., Oliveira, C.M.R. and Maranho, L.T. (2011) Efeito de extratos de casca de café (Coffea arabica L.) na germinação e crescimento de pepino (Cucumis sativus L.). Revista Brasileira de Biociências, 9, 180-186.

[18] Santos, J.C.F., Souza, I.F., Mendes, A.N.G., Morais, A.R., Conceição H.E.O. and Marinho, J.T.S. (2002) Efeito de extratos de cascas de café e de arroz na emergência e no crescimento do caruru-de-mancha. Pesquisa Agropecuária Brasileira, 37, 783-790. https://doi.org/10.1590/S0100-204X2002000600007

[19] Mazzafera, P., Yamaoka-Yano, D.M. and Vitória, A.P. (1996) Para que serve a cafeína em plantas? Revista Brasileira de Fisiologia Vegetal, Brasília, 8, 67-74.

[20] Minassa, E.M.C. (2014) Efeito alelopático da palha de café (Coffea canephora L. e Coffea arábica L.) sobre plantas cultivadas e espontâneas. Universidade Estadual do Norte Fluminense Darcy Ribeiro.

[21] Brito, A.D. (2013) Caracterização química de resíduo de café (borra) e seu efeito em cafeeiro orgânico adensado e em plântulas de cafeeiro e tomateiro. Tese de Doutorado em Agronomia, Universidade de Brasília, Brasília, 122 p. 